\title{
Palm Oil Politics in the Regent Election of Nagan Raya Aceh $2017^{1}$
}

\section{Vellayati Hajad}

Received: 30 March 2017 | Accepted: 17 August 2017 | Published: 16 October 2017

\begin{abstract}
This paper discusses palm oil politics in the regent election of Nagan Raya 2017. Palm oil politics is a term referring to the political behaviour of business people (toke), involving the palm oil land and palm oil plantation owners during the regent election of Nagan Raya 2017. Nagan Raya regency is one of the largest palm oil producers in Aceh, where there are at least 18 companies and proprietorships in operation. This research is a qualitative research aimed to determine the motivation and participation of toke sawit in the regent election of Nagan Raya. Toke Sawit's are businessmen dependent on the state for business licensing and expanding land-use, which are related to environmental protection issues such as avoiding responsibility for ecological damage. Thus, some participate in regent politics by becoming a candidate and others act as supporters of regent candidates in the form of providing funds and mobilizing workers in their plantation. Motivation of toke sawit is to get ease of doing business and have a role reinforcement of land conversion and deforestation issues.
\end{abstract}

Keywords: palm oil politics; business people; regent election

\section{Introduction}

This research discusses the political behaviour of business executives (toke) in the 2017 Nagan Raya Regent election. Toke is a term attached to individuals who are involved in the business world, and in this essay the word 'toke' refers to business executives of palm oil plantations. They are the ones who own the palm oil plantations and processing plants. This study focuses on toke sawit's behaviour towards and when the Nagan Raya regent election took place in 2017, particularly in association with toke sawit's political behaviour by being a regent candidate or being a candidate's supporter who

This work was supported and financed by the BUDI DN-LPDP (Scholarship Fund Management Institution). All opinions, findings, and conclusions are derived from the research and do not reflect the BUDI DN-LPDP. 
gives supports financially or non-financially. Furthermore, this essay discusses the relation of toke and the government and that of toke and the plantation workers in Nagan Raya Regency.

The process of the Nagan Raya regent election was enlivened by the overlapping relations between business and politics. The regent election process in this political capitalization era is related closely to political funding. During the candidacy until the election period a huge amount of funding is needed by the candidates to approach big business executives to entice them to be donors and fund the election process, and in the case of the Nagan Raya Regency the big business executives who dominate the regional economic gear are the palm oil business executives (toke sawit). In return, in the post-election period, the elected regent will give his/her loyalty to his/her political and business clients, rather than to the constituents who have voted for him/her. In its development, in the post-election the capital owners (toke sawit) will play a role as the local strongmen (Migdal, 2001). They will control and dictate official government policies especially those concerning palm oil plantations. This pattern might happen because the elected regent (toke sawit) owns a big role in terms of financial supports in the middle of capitalization of the democracy market and the involvement of toke sawit makes the democracy market more open and high-valued, so as a result, the cost needed for joining the election process becomes higher.

In the 2017 Nagan Raya regent election, issues of palm oil plantations such as licenses, land conflict and deforestation are strongly linked to other electoral issues as a form of power relations as well as political marketing and strategy to win one of the regent candidate positions. The relationship between regent candidates and toke sawits might occur due to the crossover of interests between toke sawits who demand the convenience of obtaining land conversion licenses for their business expansion and the regionalleaders who need funding resources in the election. The rampant "sale" of plantation licenses after the regent election (it can be investigated from the previous regent elections) impacts on the increase of deforestation 
in Nagan Raya. Protection of forest areas keeps decreasing and they are replaced by palm oil plantations. The limitless autonomy granted by the central government is abused by the regional government. In this case by their position, the regents have a legal right to give the licenses of land conversion into plantations. The expansion of palm oil plantations which has happened in Nagan Raya is performed by a number of big, moderate and small scale companies as well as individual companies (proprietorships).

This study was conducted to give contribution to the discussion and debate on business and political relations especially in the palm oil sub-sector. In particular, this study aims to answer the questions "What are the forms of participation of toke sawit in the Nagan Raya regent election?; Is it different from toke's participation in other sub-sectors in the agriculture sector such as toke kelapa?; then, what are the motives of toke sawit in their political participation?" by employing qualitative research method with a case study approach (Craswell, 2014). This study endeavours to identify the behaviour of toke sawit in the politics in the 2017 Nagan Raya regent election. This study was conducted in Nagan Raya Regency, Aceh Province. The interviewed informants in this research include oil palm business executives, members of political parties, workers (labourers), and Nagan Raya people listed as voters.

\section{Democracy and the 2017 Nagan Raya Regent Election}

A district head election is a circulation of political actors in the mechanism of procedural democracy. It is characterized by a shuffle between old actors and new actors who are elected in the political process every five years. Democratisation and decentralisation in Indonesia has opened opportunities to change local politics in various regions. With these dynamics, the political actors on the local level do political mobilisation based on identity, for example, clan, ethnic group, religion, and language. In the meantime, these political actors also use networks (bureaucrat and business executives) and 
ultimately, the candidates with the strongest personal networks will win the election.

A competition of being district heads demands continuous network maintenance in the region and becomes a relatively costly process for national political parties. Political parties do not have sufficient funds and facilities to support the candidates during the process. Most of political parties in Indonesia nowadays are established "on the air." In other words, they do not have any constituents in local regions. They only have the masses which are mobilised during the campaign period. These parties are also poor and cannot help the candidates solve their financial problems. This condition that is happening to the parties on a substantial level has brought political actors to seek an alternative basis directed to the political power, that is, the basis that could supply and provide political facilities such as campaign teams and access to electoral power. Personalisation of local politics, where the political actors rely on personal and influential networks - such as establishing relationships with local business executives as political fund contributors or district head candidates instead of attempting to build a constant relationship with the constituency parties-is a phenomenon that can be observed throughout Indonesia.

The phenomenon of the rising value of capital/financial factors in district head elections is not a new phenomenon. Capital or finance possessed by business executives is a social relation in an exchange system (Halim, 2014). It means that capital can be used to maintain the masses' loyalty to the business executives. Thus, it is in line with the statement that capital is the most vital factor in the arena of local politics such as regional elections (Zamroni, 2007). The established patronage relationship between elites and the masses after the fall of New Order power in the form of decentralisation, in fact, has unsettled the security role of local political elites. During the New Order (Orde Baru), the roles of state were extremely dominant and the appearance of the roles of local political elites could never be without government interference. Hence, what happened was 
the local political elites often played their roles to realise central government's interests instead of realizing the interest and the needs of their local region, or it can be said as the extension of state or government efforts to co-opt society.

Aside from influencing the relationship between elites and the masses, the changes after decentralisation also affect the relationship between elites and the state government. These changes make the masses no longer become the passive objects in their relationship with the elites. Also, to maintain their position the elites cannot rely on government only. They need to be able to calculate tactically to attain and sustain their power. In addition, it can be stated that in the elite internal circle a new set of dynamics occurs, where all of the elites are competing to sustain their position and roles.

The relationship between business and politics has always been a concern for further observation, especially if business and political relation practices take place at the provincial level. By using the economic political approach, business executives' behaviour who are involved in politics could be seen as the expression of economic interests owned by the business executive (Hutchcroft, 1998). This economic political approach could help read business executives' life behaviour which is built through a more diluted alliance with the government where the political and business motives are intertwined and support each other, especially for the business executives who work in the growing palm oil plantation sector (state dependent). A good relation between business executives and government can support economic interests of the business executives and in the same time can be used as a 'weapon' for their political interests (Hadiz, 2014). It happens differently for the 'market dependent' business executives such as coconut executives. They are not dependent on the government and must strictly follow market regulation.

A number of recent studies show that the involvement of toke in regional elections is because they are wealthy and able to influence government policy making. This power enables them to take a side of their own interests by political lobbying and even 
by being a leader of a government, that is by being a candidate in regional elections. Recent positions in government are likely to be controlled by particular business executives with a strong business network (Morck, 2004). To see the motivation of business executives, 'private-interest of government' theory can be used. This theory helps to see why a toke is involved in politics by being a regent candidate. According to this theory, the reason is because of internal motivation or they are self-motivated, and as revealed by being a leader (a regent), the toke can use their power to perpetuate policy and even expand their economic power.

Palm oil is one of Indonesia's fastest-growing and-developing economic sectors. The increase can be seen from crude palm oil (CPO) production which rises 12 percent per year. This growth contributes many vital economic benefits, but also triggers a threat for Indonesia's environment particularly the protected forests and it frequently generates social conflicts. The ownership of palm oil business nowadays is managed by companies and individuals. The same arrangement happens in Nagan Raya Regency. The majority of protected forest and peat swamp forest, havens for endangered flora and fauna, have been converted into palm oil plantation areas along with the processing plants of fresh fruit bunches or Tandan Buah Segar (TBS) into Crude Palm Oil (CPO).

Figure 1. Distribution Map of Palm Oil Plantation Land in Nagan Raya

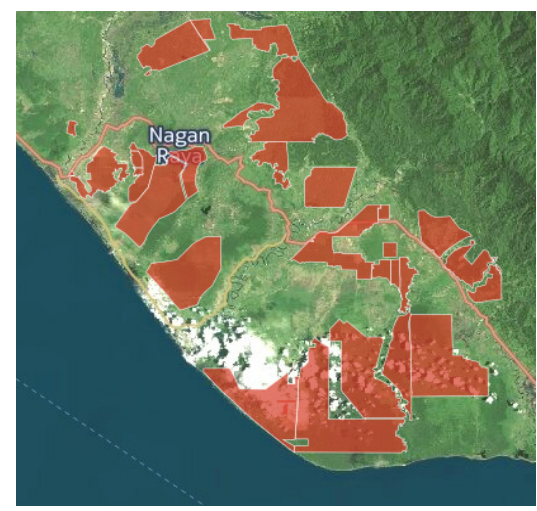


Social conflict between big companies and society have become a common event that often occurs in the areas surrounding the palm oil plantations in Nagan Raya. Generally, the conflict relates to dispute over land which belongs to the local society but is taken over by companies, land boundaries conflict, and also there are concerns about environmental pollution such as factory waste which is not well managed by the companies.

\section{Nagan Raya Regency in Context}

Based on Constitution No. 9 Year 2002, Nagan Raya regency was formed and became one of the newly reformed administrative regions from Aceh Barat regency in Aceh Province. Presently, there are at least 10 sub-districts in the Nagan Raya regency.

Table 1. Total Population of Nagan Raya

\begin{tabular}{|c|l|c|}
\hline No & \multicolumn{1}{|c|}{ Sub-districts } & Total Population \\
\hline 1 & Beutong & 13914 \\
\hline 2 & Beutong Benggalang & 1863 \\
\hline 3 & Seunagan Timur & 13521 \\
\hline 4 & Seunagan & 16079 \\
\hline 5 & Suka Makmue & 8914 \\
\hline 6 & Kuala & 20593 \\
\hline 7 & Kuala Pesisir & 15670 \\
\hline 8 & Tadu Raya & 12430 \\
\hline 9 & Darul Makmur & 43.311 \\
\hline 10 & Tripa Makmur & 8763 \\
\hline
\end{tabular}

Source: Central Bureau of Statistics of Nagan Raya Regency 2015

Conditions of the socio-cultural life of the Nagan Raya society are conducive for the implementation of development programs. The Nagan Raya regency society mostly consists of ethnic Acehnese, followed by Javanese, Batak, Minang, Chinese and Gayonese. Economically, the Nagan Raya regency is considered a 
good area in order to cultivate a variety of plantation, forestry, and agricultural commodities. This production happens because the area still has land area for agricultural cultivation and is supported by a clement climate with stable levels of rainfall each year. Therefore, various commodities of agricultural can be planted in this area, for example, staple crops (rice and palawija) and plantation crops (palm oil, coconut, and rubber).

Table 2. Plantation Commodities of Nagan Raya

\begin{tabular}{|c|l|c|}
\hline No & \multicolumn{1}{|c|}{ Types of Plantation } & Hectare \\
\hline 1 & Kelapa Sawit & 41.436 .80 \\
\hline 2 & Coklat/Kakao & 5.277 .30 \\
\hline 3 & Karet & 7.904 .06 \\
\hline 4 & Kelapa & 1.450 .80 \\
\hline 5 & Pinang & 635.40 \\
\hline
\end{tabular}

Source: Central Bureau of Statistics of Nagan Raya Regency 2015

Especially in the case of palm oil, the plantation sector has given a sizeable contribution for society development. It can be proven by the presence of 18 plantation companies which are active in processing commercial grade palm oil from crude palm oil in Nagan Raya regency. Moreover, there are also some local companies and society companies (Perkebunan Inti Rakyat or PIR) which operate various types of plantation crops.

Table 3. List of Nagan Raya Palm Oil Companies

\begin{tabular}{|c|l|c|l|}
\hline No & \multicolumn{1}{|c|}{ Companies } & No & \multicolumn{1}{|c|}{ Companies } \\
\hline 1 & PT Kalista Alam & 10 & PT Beurata Subur Persada \\
\hline 2 & $\begin{array}{l}\text { PT Socfindo } \\
\text { (Seumayam) }\end{array}$ & 11 & PT PN 1 Darul Makmur \\
\hline 3 & PT Socfindo (Seunagan) & 12 & PT Usaha Semesta Jaya \\
\hline 4 & PT Ujong Neubok Dalam & 13 & PT Usaha Sawit Sejahtera \\
\hline 5 & PT Surya Panen Subur 2 & 14 & PT Fajar Baizuri \& Brothers \\
\hline
\end{tabular}




\begin{tabular}{|l|l|l|l|}
\hline No & \multicolumn{1}{|c|}{ Companies } & \multicolumn{1}{c|}{ No } & \multicolumn{1}{c|}{ Companies } \\
\hline 6 & PT Watu Gede Utama & 15 & PT Surya Panen Subur \\
\hline 7 & PT Glumpang Raya & 16 & PT Beutrang Aceh Nanggroe \\
\hline 8 & PT Glora Sawita Makmur & 17 & PT Ambya Putra \\
\hline 9 & PT Usaha Semesta Jaya & 18 & PT Oscar Muda Dilaga \\
\hline
\end{tabular}

Source: Plantation Board of Nagan Raya 2017

Compared to businesses in most palm oil plantation sectors which are state-dependent (in terms of regulation and environmental issues), the coconut business tends to follow market demand or is market dependent. As a result, the price of coconut is influenced by the number of public demands in Nagan Raya and the surrounding districts. The palm oil business is still operating traditionally in terms of cultivation and marketing. Coconuts which have been harvested are usually sold directly to the market and are not processed again into another form. Coconut business is also not influenced by the export policies of the government because it only meets the local needs of the Acehnese people.

\section{Political Participation of Toke Sawit in 2017 Nagan Raya Regent Election}

Business executives in Nagan Raya Regency also take roles to be involved in politics. This regency is one of the regencies in Aceh which has become a basis of some of the biggest palm oil plantations. Thus, the presence of toke sawit in politics is not peculiar. Palm oil business is a vital business in Nagan Raya which can activate the regency's economy. Palm oil plantation areas reach more than $19.000 \mathrm{Ha}$ and are managed by more than 18 companies and individual proprietaries. Therefore, if it is seen from social aspects, the business of palm oil plantation has been able to provide jobs for society and participate in reducing the unemployment rate while also improving the general social welfare of Nagan Raya society. Currently, more than 45,850 people in Nagan Raya are registered as workers in palm oil plantations. 
To simplify the illustration, there are two types of toke sawit. There are those who own plantation land less than $10 \mathrm{Ha}$ called small toke because they have smaller influence, while those who own plantation land greater than $10 \mathrm{Ha}$ with many plants are called big toke because they have bigger influence in society. These levels of influence are also determined by the number of workers employed by toke sawit. Besides having more workers in the palm oil plantations and palm oil processing plants, big toke sawits also provide a better management of workers' welfare, for instance giving housing facility, health insurance, occupational accident insurance, monthly rice ration, and other bonuses aside from monthly salary. Meanwhile, small toke sawits only provide monthly salary and housing (if the plantation is located in a far place). Therefore, when the regional election is held, the workers commonly support the candidates supported by their toke sawit. Nevertheless, there are also some workers who have their own choice and do not follow their toke sawit.

In the 2017 Nagan Raya regional election one of the toke sawits ran for the regent position. Then, in fact, this toke sawit won the election with a substantial difference of votes compared to the other candidates. Hence, Nagan Raya as a regency provides an area of study to see how, in the 2017 regent election, a candidate who is a toke sawit (the owner of palm oil plantations and palm oil processing plants) won the Nagan Raya regional election. The interview with H.M Jamin Idham, the candidate who is also a palm oil business executive (toke sawit) explained his tim sukses (success strategy) was because of various activities before and after the regent election.

"Toke Jamin has been an oil palm business executive for decades and the vice candidate is also a business executive. The collaboration of these two executives could create a better business climate for Nagan Raya economy. Moreover, they are also supported by the majority of Nagan Raya people" (Interview, February $12^{\text {th }}, 2017$ ).

Tokes as candidate supporters do not always support the same Nagan Raya regent candidate. They give their supports for different 
candidates, which means that there is no similar vision or shared interests among toke sawit although all of them are involved in this supporting activity of palm oil plantation production.

One of the anonymous toke sawits stated the following view:

"I support the candidate who cares about oil palm business in Nagan Raya, for example by giving free oil palm seeds like what was done by previous regent. It is really good and helps oil palm business in Nagan Raya become more developed" (Interview, February $5^{\text {th }}, 2017$ ).

It commonly can be mapped two types of toke sawit that was involved in the election of the Nagan Raya regent 2017 first as supporter of the candidates and second as a candidate for the district head as done by H.M Jamin Idham (toke Jamin). In the following, it is presented a brief description of occupational background of the Nagan Raya regent candidates.

Table 4. Candidate Names and Profession

\begin{tabular}{|c|l|l|}
\hline No & \multicolumn{1}{|c|}{ Candidate Names } & \multicolumn{1}{c|}{ Profession } \\
\hline 1 & Teuku Raja Keumangan SH MH & Bureaucrat \\
\hline 2 & Faisal A Qubsy & Businessman \\
\hline 3 & Drh Muhammad Zahed & Bureaucrat \\
\hline 4 & Nurchalis SP & Bureaucrat \\
\hline 5 & HM Jamin Idham & Businessman (palm oil) \\
\hline
\end{tabular}

Source: Regional General Elections Commission of Nagan Raya Regency 2017

\section{A. Toke as Regent Candidate}

The winning candidate of the Nagan Raya regional election is a toke sawit who owns palm oil plantations and palm oil plants. $\mathrm{He}$ is H.M Jamin Idham. His company is PT. Ujong Neubok Dalam located in Nagan Raya. As a toke sawit, Jamin Idham has hundreds of workers. He also lives in a densely populated area which makes his electability high. Hence, H. Jamin Idham ran for regent via Partai Aceh (PA), Partai Demokrat, Partai Gerindra, Partai Bulan Bintang 
(PBB), and Partai Kebangkitan Bangsa (PKB).

Without undermining the role of Partai Aceh as the main supporting party and the capital strength owned by the regent candidates, the appearance of toke Jamin is also considered to be the 'antithetical' community of the long awaited new leaders in Nagan Raya. After the division into a new regency (almost 15 years), in fact Nagan Raya District was led by a central figure of T. Zulkarnaini or Ampon Bang who is also the brother of the candidate regent $\mathrm{T}$. Raja Keumangan (TRK). So the appearance of T. Raja Keumangan (TRK) in the prospective exchanges is considered as an extension of petahana hands. An interview with Jusmi (Interview, February $12^{\text {th }}$, 2017), one of HM Jamin's supporter team members confirmed this.

"... it is time for Nagan Raya to be led by a new person so that there is a change, not the same people and the same family, Nagan Raya district is like a kingdom then".

The interaction pattern between toke Jamin and the workers in his palm oil plantation is also interesting to be observed further. Within the structure of the Nagan Raya community, the palm toke occupies a significant place in the high hierarchy or high class society. The same is true for toke Jamin who had started the palm oil business since ten years ago. For many years, his palm oil business continues to grow and absorb a lot of manpower in Nagan Raya as well as to reduce unemployment. Toke Jamin provides jobs, moral support and other economic assistance in times of urgency so that workers give their loyalty that is by voluntarily choosing to support and vote for toke Jamin.

The advantage owned by toke sawit is that their workers are strongly tied to the moral duty that they have to the toke. As a result, when the regional election is held, the mobilization of workers to vote for the candidate recommended by the toke will be easier and massive. Near the period of Nagan Raya regional election the issue of land conversion from protected forest into palm oil plantation was getting stronger. On the other hand, the issues of deforestation 
or damages and the reduction of protected forest area are discussed more intensively by society. Amid the tough business competition, business licenses from the regional government are extremely important. It includes the license of plant/factory establishment and cultivation right on lands (Hak Guna Usaha or HGU) owned by the state. Additionally, the closeness of toke and authority/power, which in this case is the regional government, is vital to expand the existing business and to avoid responsibilities for environmental pollution and forest damages.

One of the community leaders of Nagan Raya who got in conflict with a palm oil company (PT Kalista Alam) said:

"I will not vote for a regent who supports a company that likes grabbing community land, the regent who supports such tyrannical companies must be a tyrannist". (Interview, February $5^{\text {th }}, 2017$ ).

\section{B. Toke Sawit as Candidate Supporter}

Great wealth ownership makes a toke sawit to be respected in Nagan Raya. Nevertheless, they often do not want to be regent or regional leader. They tend to focus on their palm oil business and expand their business network. Toke sawit is not a type of businessman who depends on the government. There are some issues which make toke sawit to establish good relationship with the regional government, for example, land issues and business licenses often involve their own palm oil business along with the issue of pollution and environmental damage.

Just as T. Raja Keumangan (TRK) did in the past, he also required additional funds in the present election. To run for regent or mayor the candidates need significant funds at least 1.8-16 billion rupiahs (Rinakit, 1995). This money is needed by the candidates to pay "rent expense" for the political party in order that the party is willing to nominate the candidate in regional elections, build winning post networks, employ tim sukses, pay for campaign advertisements in media, employ consultants and spokesperson, including paying for the invited entertainers in the campaign period. 
Therefore, the presence of palm oil toke in supporting the candidates is a common thing to be encountered, especially in Nagan Raya whose largest capital owner is toke of palm oil. Toke of palm oil will receive assistance in the form of open and hidden campaign support depending on the level of need for 'reply' obtained after the elected candidates. For indeed, the competing toke sawit who expect aid in business licensing (establishment of factories, use and expand of plantation) and are protecting their business from investigation, such as from pollution and damaged environment usually are more militant in giving support. Various forms of support are given by toke sawit. First, toke have economic resources such as money and facility of factories. Second, toke have strong and organized supporters who can be mobilized for winning the candidacy. Third, there are many toke sawit who compete with each other in supporting potential candidates to win. And then, it becomes an unwritten agreement that toke sawit reflect the strength of a promoted candidate.

\section{Financial Funding}

The entrance of toke sawit in politics begins from the closeness of toke sawit and the candidates. It also because there are donations from individual and private legal entities for candidates as stated in Regulation number 32 year 2004 article 83 about donations for candidates, which provides big opportunity for political parties, individuals, and private legal entities in giving donations for candidates without passing the prescribed limit (Wahidin, 2008). Toke sawit act in the electoral field as supporters or candidates and as a form of necessity in huge political funding mobilisation in candidate activities. The funds are needed to rent political party boats, funds for building physical facilities for enclaves, expenses for image building and image bubbling and many more political propaganda (Leo, 2009).

The necessity of political funding finally means approaches by the toke sawit to the candidate. Although funds are not only a 
factor in deciding the victory, the political funding gives big impact for the current political constellation. Toke sawit will do political communication through regular meetings with the candidate and then toke will offer support in the form of worker mobilization in order to choose a candidate and give access in using company facilities such as using of their trucks as media campaign or even in giving funding (money) to a candidate directly or indirectly. This was revealed in an interview with members of the Golkar Party when one of the party supporting T. Raja Keumangan represented by Diar Sudarlin (Interview, February $11^{\text {th }}, 2017$ ) said as follows:

"Nowadays, many donors have come to provide funding support for our candidates (T. Raja Keumangan), the extent of this support shows the enthusiasm of the people in the election process, and we are optimistic that our candidates will win the election".

Although it cannot be denied, all forms of support provided by palm oil toke to the candidates of the regent aim to open access in government, especially after the election process takes place. When the new regent has been inaugurated, the palm oil toke can influence the decision-making process and the government's policy-making process according to their interests (political exclusivism) and what is feared by many observers of the election involves political corruption (Sugiarto, 2009). Toke Sawit as businessman in the palm oil area depend on the government in relation to use of land licenses or HGU (hak guna usaha or cultivation rights) and factory establishment licenses. They also hid behind regional government through using formal authority owned by state officials for their business concerns especially when there is conflict with society related to land conflict border and conflict caused by land pollution of waste or air pollution. Based on Undang Undang Pemerintahan Aceh (UUPA), land tenure is divided to become land tenure which has special authority namely public and civil authority and land tenure given public authority namely authority in civil field in ownership and land use according to type of land tenure. Hak Guna 
Usaha (HGU-cultivation rights) can be given for maximum periods of 35 years and are based on demand right holders and consider about company maximum extended 25 years. Then, if the period of HGU and extension has expired, the right holders can get new HGU in the same land.

\section{Non-Financial Funding}

There are some forms of non-financial funding of toke sawit in supporting a candidate such as supporter mobilisation. Toke sawit as the owner of a palm oil factory has huge influence in society because they are able to mobilise the employers and workers in the factory or plantation in order to choose one of the candidates. Also, the difficulty of getting a job in Nagan Raya makes more strengthened the position of the toke in society. In addition, the workers should follow the rules or policy of the owner of factory who wants them to support and socialize the candidate. Besides that, toke sawit also establish many winning posts for candidates. Posts are considered as effective media in order to introduce supported candidates to society. Building posts is usually located in the toke's house and warehouses because it is easy to access and a place for supporters to gather (Firmanzah, 2010). Establishment of winning posts is a strong indicator for toke sawit because the support comes together for one of the candidates. In addition, it also proves that toke's facility can be used as a non-financial modal so that he will make an offering to support candidate's win in the next day election. Campaign attribute is another important element in the campaign process. Thus, the toke provides and uses campaign attributes of supported candidates to convince society to follow his decision. The campaign attributes include such promotional as billboards, banners, posters, and shirts, even to cover their personal cars and company cars with posters and stickers promoting candidates. Diar Sudarlin (Interview, February $\left.15^{\text {th }}, 2017\right)$ also added the following: 


\begin{abstract}
"Every supporter of a candidate has a name for his group and can usually be seen easily on stickers attached to homes and vehicles (motorcycles and cars), and becomes a symbol of strong support to one of the candidates, even colours can distinguish on which side the community is. They are red (toke Jamin) or yellow (T. Raja Keumangan)".
\end{abstract}

The political behavior of palm toke does not depart from the existence of patron and client relations in Nagan Raya. This pattern is because the economic sector of Nagan Raya Regency depends heavily on palm oil production. Therefore, patron-client relationships based on palm oil business are very strong. Toke sawit is a patron within the scope of Nagan Raya as a figure whose power or position provides security guarantees, inducements or both, and ownership of clients or workers who are individual followers of the palm toke who always provides loyalty and personal assistance. In addition to business factors, the relationship between a palm toke and workers is also fostered by emotional bonds of loyalty. Emotional bonding becomes an important part of this relationship because it will create a sense of solidarity and mutual trust.

\title{
Oil Palm Politics of Toke Sawit in the 2017 Nagan Raya Regent Election
}

Toke sawit who have control on resources such as power, status, and wealth utilise their resources and it is interchanged or exchanged with the loyalty of workers. This aims to increase selfelectability or support for the candidate. Based on research, each toke sawit has different political preferences and it can be seen in the way they give support to candidates. The Company of HM Jamin Idham, PT. Ujong Nebok, has hundreds of workers. Hence, their policy of this company appealed to the workers to choose HM Jamin Idham in Nagan Raya election. This happened because HM Jamin Idham's victory determines the fate of the workers.

An interview with one of the anonymous workers of PT. Ujong Neubok Dalam (43 years old) states: 
"My friends and I choose toke Jamin as regent because he gives us a job. Also, if toke Jamin win, we will be prosperous" (Interview, February $20^{\text {th }}$, 2017).

The workers assume that toke Jamin holds a lot of resources needed by the workers in the plantation so that they can survive and live in Nagan Raya such as jobs and houses (including the facilities). Hence, toke sawit can be categorized as a patron. Meanwhile, the plantation workers, who in this case do not own resources, become clients who need toke Jamin as their patron in order to give protection and advantage. As an exchange, the clients offer general support and help including personal services to the patrons. Both parties in this patron-client relationship establish a smooth mutual relationship. This situation reflects the gist of the traditional patronclient relationship as seen in many parts of Indonesia.

While PT. Socfindo and PT. Perkebunan Nusantara (PTPN) do not direct the workers openly to choose one of candidates, the workers are given their freedom of choice. However, the company gives financial assistance to each candidate based on a candidate's electability in the election. Nevertheless, the majority of workers in PT. Socfindo and PTPN gave their vote on candidate number 5, namely H.M. Jamin Idham, as these companies share the same location with the voting base area of Jamin Idham, namely the sub district Darul Makmur. Rahayu (Interview, February 15 ${ }^{\text {th }}, 2017$ ), one of workers of PTPN, explains:

"The company does not direct the workers to choose one of regent candidates in regent election this year. This is not like previous election where we are directed to choose particular candidate by the company. So our choices are different in this year, some of us choose T. Raja Keumangan and the other one choose toke Jamin, but most of us choose toke Jamin. It probably because toke Jamin comes from Darul Makmur and most of the workers in PTPN also comes from Darul Makmur".

The interaction pattern of toke in PTPN and the workers in the palm oil plantations in the regent election 2017 deserves to be observed. In the Nagan Raya society structure, toke sawit occupy the 
highest hierarchy as part of the high society, while the workers are subordinate and follow the toke sawit' instructions.

Nevertheless, the toke-worker relationship is asymmetric, which means that the strength or weakness of the relationship ties and the dependency between toke sawit and every worker are different, or dissimilar. It is determined by the dependency level of the workers towards the toke and it can be identified by how much moral duty they have to the toke sawit in every life problem they and their family face. As happened in PT. Kalista Alam (KA), the patronage network owned by the toke is weak and fragile where the instruction given the companies is rejected brightly by the workers. The company also has closeness to the previous regional government so that they give open support to candidate number 1 namely T. Raja Keumangan (TRK) who is the brother of the previous regent. PT. Kalista Alam gave instructions for the workers to choose number 1 namely $\mathrm{T}$. Raja Keumangan as regent in the 2017 Nagan Raya regent election, if not, then the workers will lose their job.

PT. Kalista Alam has conflict about plantation borders with society and it has been appeased by the regional government until now. Then, in keeping this situation, PT Kalista Alam openly told the workers to choose number 1 namely T. Raja Keumangan or the workers will lose their work. This situation happens because the company will get loss if the conflict still goes on. It can be assumed that this is an "empty threat" of the company. Through this rumour, it can be seen that supporting one of candidates is not only for obtaining advantages but also to prevent disadvantage, as stated by Sumi (Interview, February $10^{\text {th }}, 2017$ ) as one of the plantation workers in PT. Kalista Alam:

"...rumours say that if we do not choose T. Raja Keumangan we will lose our job. In this moment, Kalista Alam is getting land dispute case with the society and other plantation companies (toke Jamin ownership). This conflict only can be saved by T. Raja Keumangan, as done by his brother Ampon Bang (H.T. Zulkarnaini) in the past". 
It also happens that the workers in PT. Fajar Baizury \& Brothers also are asked to give open support for candidate number $1 \mathrm{~T}$. Raja Keumangan who is the brother of the previous regent. Candidate number 1 is the brother of the previous regent who became the Nagan Raya regent since becoming an independent regency. At least, it has been 15 years that T. Zulkarnain (brother of T. Raja Keumangan) became regent and sought protection for the plantation company which operates with the current land license or HGU.

The total area of the big and small companies with some individual open plantations in the peat forest of Nagan Raya regency with HGU reaches 38,150 hectares. Many toke sawit are worried if the newly elected leader will take aside environmental agencies such as Walhi, which investigate logging cases, prosecute forest fires and transfer function of forest protection to palm oil plantations so that it results in further damage to the ecosystem. Then, toke sawit chose to affiliate with the new candidate in this regional election by giving their support. With the result that the supported regent will give protection to their own asset of plantation. It salvages them from the eye of environmental agencies or endangered species protection agencies. Rawa Tripa peat forest has become in the world spotlight because of environmental damage. It happens because uncontrollable forest conversion eliminates rare flora and fauna such as the endangered orangutan. It can be said that the ecosystem of Rawa Tripa has deteriorated due to serious deforestation. Nowadays, the remaining forest is only $20.53 \%$ in the Nagan Raya regency. Thus, the toke sawit who have plantations in this area should support one of the candidates in the Nagan Raya regional election in order to safeguard their interests and investments.

Financial and non-financial funding show the work orientation of toke sawit in the election. The presence of toke sawit shows that the state institution is weak so that toke sawit choose to approach a regent candidate or even become a regent by taking part in the election in order to avoid missing an opportunity in obtaining 
political advantage with minimum cost. For easy understanding, Table 5 presents a model of the relationship between toke sawit and state.

Table 5. Model Participation of Toke Sawit in Politics

\begin{tabular}{|c|c|}
\hline State (Government) & Business (Toke Sawit) \\
\hline Strong & $\begin{array}{c}\text { Gets few political favors and } \\
\text { political participation limited }\end{array}$ \\
\hline Weak & $\begin{array}{c}\text { Receives favorable treatment and } \\
\text { may run for office to avoid the cost } \\
\text { of lobbying elected officials }\end{array}$ \\
\hline
\end{tabular}

From the above model, it can be seen that if a strong state has an elected regent or leader who emphasizes on accountability, the opportunity of toke sawit impact the public policy based on their concerns becomes limited. Similarly, if a toke sawit becomes the regent, the opportunity obtained for self-advantage becomes small. However, if there is a weak state or even if not present, a situation emerges with substantial costs in order to effect the election process so that toke sawit are able to manipulate the situation or become a candidate as regent. Therefore, this model shows that the opportunity is not only to form public policy but also to participate in regional and local politics (Bartels, 2003). On the other hand, processes between the two periods of election are more important than the actual election happening, especially for the businessmen. After the election, various issues and appointments usually are forgotten. However, the activities of the businessmen, capital owners, and landlords toward influential persons in government in the period between the two elections are more effective, for example, giving money in support of the election of a candidate or political party or providing dividends after election.

There are a number of considerations of toke sawit in participating in the political arena, such as a candidate or supporter of candidate giving licenses and extending licenses of $\mathrm{HGU}$ 
(expanding plantation), obtaining licenses of establishment palm oil factories, protecting toke from land conflicts involving plantation borders with society or other companies, while sheltering the businessmen from environmental damage and pollution issues. Giving licenses of HGU always implicates on conversion of forest land to become non forest land, and this change of land use is an ecology issue related to public policy in a protected area of concern. During the decentralisation era, the victory of a regent (a.k.a., bupati) determined the licensing process of land conversion of palm oil plantations. It cannot be avoided that expanding of palm oil plantations continues to increase and as a result reduce the forest through deforestation.

Moreover, the presence of palm oil plantations has other environmental impacts. Every step of industry and business development of palm oil plantations always causes environmental damage and degradation of the ecology, starting from clearing land, to growing, to finally processing in the production factories. Land clearing by burning is the fastest and cheapest method which is frequently used so that it causes air pollution and greenhouse gas emission. Fire for clearing land often spreads out of control so that it harms the core forest and ecosystems along with endemic flora and fauna. Palm trees also cannot save water like other plants. That is why, floods and droughts are becoming more frequent. In plantation activities, there are many physical impacts on the land areas, such as pollution from run-off waste and environmental damage.

Table 6. Election Result of Regent and Vice-Regent Candidates of Nagan Raya

\begin{tabular}{|c|l|c|}
\hline No & \multicolumn{1}{|c|}{ Regent and Vice-Regent Candidates } & Election Results \\
\hline 1 & T. Raja Keumangan-Said Junaidi & 34.474 votes \\
\hline 2 & Faisal A Qubsy-Mustafa Cut Ali & 872 votes \\
\hline 3 & drh Muhammad Zahed-Samsul Bahri & 1.267 votes \\
\hline 4 & Nurchalis MSi-Suyanto & 14.746 votes \\
\hline 5 & HM Jamin Idham-Chalidin & 1.356 votes \\
\hline
\end{tabular}

Source: Regional General Elections Commission of Nagan Raya Regency 2017 
Regent election process of Nagan Raya Regency 2017 as stated by General Election Commissions (Komisi Independen Pemilihan/ KIP) of Nagan Raya shows that political behaviour of toke sawit as a candidate managed to win the regent election by exploiting a patron/ client process significantly along with other supporting factors such as the urgent emergence of having a new candidate outside of the Teuku Zulkarnaini family and other social/economic factors.

\section{Closing}

In the Nagan Raya regent election, toke sawits play oil palm politics or politik kelapa sawit, that is by participating in the election process and by using their potential and position in the oil palm business. By having economic and social capitals (especially, in the form of workers) toke sawits' participation in political elections hastwo main roles: one being a regent candidate and the otherbeing a candidate supporter. Both of these roles are played by toke sawits to support the plantation businesses they run in Nagan Raya. Although it is not fully dependent on government, oil palm businesses are still state-dependent especially in terms of regulations and environmental issues, different from the involvement of toke kelapa which is market dependent. Palm oil business executives need the government to support and protect them from bankruptcy as well as allow then to expand their business by influencing the regional government to extend or give a new Hak Guna Usaha (HGU) license for them. Thus, electing the regent that supports the toke sawits' interests is really important for their economic prosperity.

Briefly, it can be said that palm oil politics done by toke sawits is an exchange of interests between regent candidates and toke sawits. Toke sawits have a number of funds even personal facilities and companies such as cars and houses whichcan be used as winning posts of the candidates during the campaign period. The tokes also employ workers who are loyal and obedient to the instructions and directions given by the toke sawit, so when the election takes place 
these workers can be mobilized to attend the campaign and give their votes. It can be seen from the vast number of supporters on the roads and squares during the campaign and election. In return, the elected regent will offer protection, business convenience, and give access for toke sawits in the government especially in association with regulations and policies which benefit toke sawits. The efforts of securing and expanding their wealth cane be clearly seen by their making many agreements that benefit the business of toke sawit, for instance expansion of plantation areas by getting licenses for forest conversion into plantation areas and even arrangements to protect their company from some possibilities of the investigation of environmental damages and pollution caused by the palm oil companies during land clearing and processing for the plantations. 


\section{References}

Bartels, L. \& Brady, H.E. (2003). Economic Behavior in Political Context. American Economic Review, 93 (2), 156-610.

Craswell, J. (2014). Penelitian Kualitatif \& Desain Riset: Memilih di Antara Lima Pendekatan. Yogyakarta: Pustaka Pelajar.

Firmanzah. (2010). Persaingan, Legitimasi Kekuasaan, dan Marketing Politik. Jakarta: Yayasan Obor Indonesia.

Hadiz, V. \& Robinson, R. (2014). Ekonomi Politik Oligarki dan Pengorganisasian Kembali Kekuasaan di Indonesia. Prisma, 33(1), 35-56. LP3ES.

Halim, A. (2014). Politik Lokal (Pola, Aktor, dan Alur Dramatikalnya). Yogyakarta: LP2B.

Hutchcroft, P. (1998). Booty Capitalism: The Politics of Banking in the Philippines. London: Cornel University Press.

Leo, A. (2009). Pilkada dan Dinamika Politik Lokal. Yogyakarta: Pustaka Pelajar.

Migdal, J. S. (2001). State in Society: Studying How States and Societies Transform and Constitut One Another. UK: Camridge University Press.

Morck, R. \& Yeung, B. (2004). Family Control and the Rent-Seeking Society. Entrepreneurship Theory and Practice, 28(4), 391-409.

Rinakit, S. (1995). Desentralization and Military. In P. S. Maribeth Erb, Carol Faucher (Ed.), Regionalism in Post-Suharto Indonesia. New York: Rouledge Curzon.

Sugiarto, A. B. (2009). Politik Uang dan Pengaturan Dana Politik di Era Reformas. In Wijayanto dan Ridwan Zahrie (Ed.), Korupsi Mengkorupsi Indonesia. PT. Gramedia Pustaka Utama.

Wahidin, S. (2008). Mengawasi Pemilihan Umum Kepala Daerah. Yogyakarta: Pustaka Pelajar.

Zamroni, I. (2007). Juragan, Kiai, dan Politik di Madura. UNISIA, 30 (65), 264-272. 